\title{
Influence of Heat Stress and Housing on Broiler Production: A Review
}

\author{
Nkrumah Theresah ${ }^{1,2 *}$, Tona Koukou ${ }^{2}$ and Hamidu Alhasan Jacob ${ }^{3}$ \\ ${ }^{1}$ Council for Scientific and Industrial Research, Animal Research Institute, Ghana \\ ${ }^{2}$ Laboratoire des Sciences et Techniques de Production Avicoles, Centre d'Excellence \\ Regionale des Sciences Aviaires (CERSA), Ecole Supérieure d'Agronomie (ESA), \\ Université de Lomé, Lomé, Togo \\ ${ }^{3}$ Department of Animal Science, Kwame Nkrumah University of Science and \\ Technology, Ghana \\ *Corresponding Author: Nkrumah Theresah, Council for Scientific and \\ Industrial Research, Animal Research Institute, Ghana.
}

\begin{abstract}
The success of poultry production is highly dependent on prevailing climatic and environmental conditions. Heat stress is a limiting factor in broiler production in tropical regions. Heat stress causes stunted and abnormal growth as well as poor quality and safety of broiler meat. Influence of heat stress on productivity and immune response in broiler has been adequately studied. However, little research is done on the influence heat stress and housing have on poultry production. This review focuses on the research findings available on the influence of heat stress and housing in broilers.

Keywords: Heat Stress; Broiler Production; Broiler Meat
\end{abstract}

\section{Introduction}

Poultry production is one of the lucrative businesses of the livestock industry in both developed and developing countries. According to Sinha., et al. [1] inconsistency in non-genetic factors is known to have influence on sustainability of livestock production systems in tropical environments. Heat stress causes death of birds which results decline production performance and adversely affects the return from the enterprise. Pathogens and other disease causing organisms increase with increasing temperature; resulting in outbreak of diseases in poultry birds. Variations in climatic conditions influence the occurrence of diseases and their transmission due to increase vectors and pathogens.

\section{Signs of heat stress in poultry}

Broiler birds that have heat stress usually show signs of panting with open mouth gasping for air, the combs/wattles become pale, wallowing in any available water, fatigue, constantly drink water, convulsion in severe cases, reduced feed intake, decreased weight and increased pecking, increased output of urine and further loss of electrolytes, wet droppings developed, disturbance in bone metabolism, immunity to defend the body against diseases decreases [2]. Poultry farmers can help reduce heat stress within the birds by supplying the birds with cold water, ensuring proper ventilation within the pen, constantly changing the litter within the pen because the litter could generates a lot of heat. Birds experiencing heat stress conditions, feed less, drink more water [3].
Received: March 12, 2020

Published: April 22, 2020

(C) All rights are reserved by Nkrumah

Theresah., et al.
Effects of heat stress on broiler meat

According to Dai., et al. [4], Imik., et al. [5] exposure of birds to high direct sunshine results in depression of chemical composition and meat quality in broilers industry. Heat stress causes poor meat characteristics of broiler chicken and therefore the quality of the meat is lost, especially when the birds are exposed to high temperatures during the growing phase [6]. During transportation of birds to the processing unit, birds experienced heat stress; this results in high drip loss, high $\mathrm{pH}$ leading to dark colour, low juiciness, poor meat safety [7]. Environmental stress like early feed withdrawal put the birds under more stress releasing halothane genes causing drastic biochemical break down of glycogen into lactic acid resulting into Pale, Soft and Exudative meat.

Fellenberg and Speisky [8] reported that heat stress causes oxidative stress. Oxidative stress generates free radicals, which react with proteins, carbohydrates, fats and cellular structures and disrupt their structure and functions. Oxidative stress has adverse effects on protein metabolism, decreasing the retention and increasing the excretion of proteins [9]. The easiest way to alleviate heat stress-induced adverse effects is to add natural or synthetic antioxidants and nutrients to the feed [10]. Heat stress adversely affects the structure and growth of muscles. According to Dai., et al. [4], Imik., et al. [5] exposure of birds to high direct sunshine leads to depression of chemical composition and meat quality in broilers 
industry. Exposure to high ambient temperature during the growing phase of broilers has been related with poor meat characteristics of broiler chicken and loss of quality, example it reduces drip loss in broiler meats [6]. Moreover, exposure to heat stress during transportation of birds from production farms to processing centre has led to losses of meat quality [7]. Heat stress is thought to be an element which will result into colonization of birds by pathogens, increased faecal shedding and horizontal transmission, and consequently, increased contamination risk of animal products. High heat stress increases the colonization of birds by disease causing organisms thereby reducing the security of the broiler meat; this might result in prolong stress of the bird resulting in Dark Firm Dry (DFD) meat.

Effect of heat stress on behavioural and physiological responses

Liu., et al. (2015) reported that birds under heat stress lie down longer than non-heat stress birds. When the authors compared the feeding behaviour, they concluded that heat stressed birds take shorter time to feed than non-heat stressed birds. Stressed birds drink more water than non-stressed birds. Birds under heat stress tends to reduce the impact of heat stress by feeding less and drink more.

Birds under heat stress tend to adjust the function of their central, metabolic and endocrine systems that controls thermoregulation. The physical features of the birds are influenced by the metabolic rate and can be used for behavioural adjustments [11]. Homeostasis is involved in an adaptive role in adaptation to adverse environmental conditions. The social and physiological behaviour of birds change to enable them maintain their body temperature and cope with the heat stress in the environment. The immune system of heat stressed birds tIn adverse climatic condition, maintaining homeostasis mechanism in birds is by heat exchange between environment and air sac through convection, evaporative heat loss, perspiration and vasodilation process [12].

Effect of heat stress on the immunological responses in birds

Heat stress has adverse effects on health status of birds leading to changes in physiology, metabolism, hormonal and immune system. High temperature decreases synthesis of Thymus and Bone-marrow lymphocytes and suppression of phagocytic activity of blood leukocytes [13]. It further decreases total white blood corpuscle (WBC) and activities of leukocytes subsequent heat exposure. Bartlett and Smith [14] found lower levels of total circulating antibodies and lower levels of specific IgM and IgG in broiler under heat stress. Zulkifi., et al. [15] also supported that, heat stress had significant decline in antibody production; causing variation of the immune reaction by the central nervous system (CNS) and which is mediated by a complex network of nervous, endocrine and immune systems.
Influence of deep litter system of housing on production

Birds kept on deep litter system fed better than those on grass [16]. However, birds in deep litter demonstrated high level of freight which can influence their productivity. Research conducted by Dhaliwal., et al. [17] revealed that purchasing birds kept on deep litter have higher laying capacity than those kept on the other bedding materials. Welfare of the bird is vital issue to consider in poultry keeping, since the welfare of the birds directly influence the health and productivity. In developing countries, poultry housing structures are built with consideration of environmental heat requirements of the birds. According to Glatz and Bella [18] birds kept in the tropical countries require minimal heat; which includes the housing structure, even though, newly hatched birds require supplementary heating. Deep litter system of housing birds give the birds total freedom to display give their normal patterns of behaviour (Ismail, 2017).

Influence of slated floor and deep litter on poultry production One limitation of the deep litter system of housing is reduced productivity and exposure of the birds to disease condition. This limitation can be taken care of by the employment of slated floor. In slated floor housing system, the birds' feet do not get into contact with the excreta; this ensure reduced disease conditions and increase growth rate [19]. Slated floor improves/increases the welfare of the birds [20]. In deep litter system of housing, better litter management is incredibly crucial for litter quality [21]. Poor litter and ventilation put the birds at the risk of respiratory diseases and dermatitis. As a result of poultry improvement and breeding programmes that have been carried out in the last 40 - 50 years, performance of broiler chickens has improved by the developments of feeding, environmental conditions, and health improvements [22]. Also, the weight and feed conversion ratio of the birds have also been improved during the growth phase drastically [23]. Notwithstanding this fast growth rate, it has led to undesirable outcomes, which are one of the main concerns in animal welfare. Bessei [24] indicated that fast growth rate is associated with metabolic diseases, lower locomotor activity, high stocking density, and bad management of air and litter quality in the housing unit. Fast-growing broilers show higher rates of heart attack and hypoxia [25] and are more prone to behavioural disorders and immune system impairments [26]. There is a negative impact on the welfare of the birds due to the fast growth rates. Either different feeding regime is advised to control the growth rate of commercial broilers [27]. Animal welfare activists and scientists recommend deep litter system. Deep litter system is mostly used for brooding and rearing chicks and broiler however, it can also be used for rearing layer birds. Deep litter rearing helps to reduce stress in laying birds (Ismail, 2017).

Modern broiler chickens are kept in deep-litter houses with wood shavings used as bedding materials where the quality of litter 
material and good ventilation is ensured to prevent the well-being of the birds [28,29]. Since, broiler birds spend most of their time resting, especially after 3 weeks of age. The quality and quantity of litter influences indirectly the level of heat generated in the pen. High levels of ammonia in litter is known to cause inflammation of eyes and larynges of the birds and has a high probability of increasing the rate of mortality [30]. The growth rate of the birds may be negatively affected when the feet of the birds are in contact with manure and the litter [19]. Dermatitis in broiler chicken is caused by wet litters which significantly influence the health and the welfare status of the birds and subsequently the total profitability $[30,31]$. The occurrence of foot-pad dermatitis do have significant welfare and financial implications [32].

Due to the problems of poor litter management associated with deep-litter production systems, alternative floor systems is suggested in commercial broiler meat production [33]. Most poultry farmers prefer deep litter system to cages and slatted floor because of low cost of production in the usage of deep litter system. Due to the adverse effects of wet litter on the birds for instance leg deformities and breast blisters that negatively affects broiler meat quality, farmers now prefer cage systems [34]. It has been thought that slatted floors would become more popular since they have no litter cost and they minimize the negative effects of improper litter management $[33,35]$.

\section{Conclusion}

This review focuses on the research findings available on the influence of heat stress and housing in broilers.

\section{Bibliography}

1. Sinha R., et al. "The impact of climate change on livestock production and reproduction: ameliorative management". International Journal of Livestock Research 7.6 (2017): 1- 8.

2. Dayyani N and Bakhtiyari H. "Heat stress in poultry: background and affective factors". International Journal of Advanced Biological and Biomedical Research 1.11 (2013): 14091413.

3. Mack LA., et al. "Genetic variation of production and behavioural responses following heat stress in two strains of laying hens". Poultry Science 92 (2013): 285-294.

4. Dai SF, et al. "Effects of dietary glutamine and gamma amino butyric acid on meat colour, $\mathrm{pH}$, composition, and water-holding characteristic in broilers under cyclic heat stress". British Poultry Science 53 (2012): 471-481.

5. Imik H., et al. "Meat quality of heat stress exposed broilers and effect of protein and vitamin E". British Poultry Science 53 (2012): 689-698.
6. Zhang ZY., et al. "Effects of constant and cyclic heat stress on muscle metabolism and meat quality of broiler breast fillet and thigh meat". Poultry Science 91 (2012): 2931-2937.

7. Dadgar S., et al. "Effect of microclimate temperature during transportation of broiler chickens on quality of pectoralis major muscle". Poultry Science 89 (2010): 1033-1041.

8. Fellenberg MA and Speisky H. "Antioxidants: their effects on broiler oxidative stress and its meat". World's Poultry Science Journal 62 (2006): 53-70.

9. De Faria Filho DE., et al. "Protein levels for heat-exposed broilers: performance, nutrients digestibility, and energy and protein metabolism". International Journal of Poultry Science 6 (2007): 187-194.

10. Lin H., et al. "Strategies for preventing heat stress in poultry". World's Poultry Science Journal 62 (2006): 71-85.

11. Cooper CE and Geiser F. "The "minimal boundary curve for endothermy" as a predictor of heterothermy in mammals and birds: a review". Journal of Comparative Physiology B-Biochemical Systemic and Environmental Physiology 178.1 (2008): 1-8.

12. Mustaf S., et al. "Intermittent partial surface wetting and its effect on body-surface temperatures and egg production of white brown domestic laying hens in Antalya (Turkey)". British Poultry Science 50 (2009): 33-38.

13. Monson MS., et al. "Immunomodulatory effects of heat stress and lipopolysaccharide on the bursal transcriptome in two distinct chicken lines". BMC Genomics 19.1 (2018): 643.

14. Bartlett JR and Smith MO. "Effects of different levels of zinc on the performance and immuno-competence of broilers under heat stress". Poultry Science 82 (2003): 1580-1588.

15. Zulkifi I., et al. "The effect of early age feed restriction on subsequent response to high environmental temperatures in female broiler chickens". Poultry Science 79 (2000): 1401-1407.

16. Oke OE., et al. "Effect of Deep Litter System with or without Access to Grass or Legume Pastures on Egg Fatty Acids and Proximate Composition of Laying Hens". Pacific Journal of Science and Technology 14.2 (2013): 433-440.

17. Dhaliwal APS., et al. "Effect of various deep litter systems on the performance and profitability in egg laying birds". Journal of Pharmacognosy and Phytochemistry 7.6 (2018): 433-436.

18. Glatz PC and Bella G. "Production systems, poultry". In Encyclopaedia of meat sciences (2004): 1085-1092. 
19. Chuppava B., et al. "Effect of Different Flooring Designs on the Performance and Foot Pad Health in Broilers and Turkeys". Animals: An Open Access Journal from MDPI 8.5 (2018): 70.

20. Çavuşoğlu E and Petek M. "Effects of different floor materials on the welfare and behaviour of slow- and fast-growing broilers". Archives of Animal Breeding 62.1 (2019): 335-344.

21. Aviagen. "A guide to managing broilers in open-sided housing" (2016).

22. Fanatico AC., et al. "Meat quality of slow-and fast-growing chicken genotypes fed low- nutrient or standard diets and raised indoors or with outdoor access". Poultry Science 86 (2007): 2245-2255

23. Goliomytis M., et al. "The effects of quercetin dietary supplementation on broiler growth performance, meat quality, and oxidative stability". Poultry Science 93 (2014): 1957-1962.

24. Bessei W. "Welfare of broilers: a review". Poultry Science Journal 62 (2006): 455-466.

25. Julian RJ. "Production and growth related disorders and other metabolic diseases of poultry - A review". Veterinary Journal 169 (2005): 350-369.

26. Rauw WM., et al. "Undesirable side effects of selection for high production efficiency in farm animals: A review". Livestock Production Science 56 (1998): 15-33.

27. Dawkins MS and Layton R. "Breeding for better welfare: Genetic goals for broiler chickens and their parents". Animal Welfare 21 (2012): 147-155.

28. Berg C. "Health and welfare in organic poultry production". Acta Veterinaria Scandinavica 43 (2002): 95-100.

29. Bergmann S., et al. "Behaviour as welfare indicator for the rearing of broilers in an enriched husbandry environment - A field study". Journal of Veterinary Behavior: Clinical Applications and Research 19 (2017): 90-101.

30. Shepherd EM and Fairchild BD. "Footpad dermatitis in poultry”. Poultry Science 89 (2010): 2043-2051.

31. Dunlop MW., et al. "The multidimensional causal factors of "wet litter" in chicken-meat production". Science Total Environment 562 (2016): 766-776.

32. De Jong IC., et al. "Wet litter not only induces footpad dermatitis but also reduces overall welfare, technical performance, and carcass yield in broiler chickens". Journal of Applied Poultry Research 23 (2014): 51-58.
33. Petek M., et al. "Effects of age at first access to range area on pecking behaviour and plumage quality of free-range layer chickens". Arch Tierzucht 58 (2015): 85-91.

34. Özhan N., et al. "Comparison of floor and cage housing systems in terms of some welfare assessments in broiler". Kafkas Üniversitesi Veteriner Fakültesi Dergisi 63 (2016): 317-322.

35. Nardone A., et al. "Effects of climate change on animal production and sustainability of livestock systems". Livestock Science 130 (2010): 57-69.

\section{Assets from publication with us}

- Prompt Acknowledgement after receiving the article

- Thorough Double blinded peer review

- Rapid Publication

- Issue of Publication Certificate

- High visibility of your Published work

Website: https://www.actascientific.com/

Submit Article: https://www.actascientific.com/submission.php Email us: editor@actascientific.com

Contact us: +919182824667 


\begin{tabular}{|c|c|c|c|}
\hline $\begin{array}{l}\text { Nutritional/Dietary } \\
\text { components }\end{array}$ & Influence on microbiota & Influence on host health & Reference \\
\hline Whole Grain Diet & $\begin{array}{l}\text { Relative abundance of Enterobac- } \\
\text { teriaceae decreased; Butyrate-pro- } \\
\text { ducing Lachnospira and Roseburia } \\
\text { increased. }\end{array}$ & $\begin{array}{l}\text { Energy balance regulation, Plasma alkyl- } \\
\text { resorcinols increased and maintained body } \\
\text { weight. }\end{array}$ & Karl JP., et al. [57] \\
\hline Low Carbohydrate Intake & $\begin{array}{l}\text { Decreases Eubacterium rectale, Bifi- } \\
\text { dobacterium and Roseburia species }\end{array}$ & Unclear. & Murphy EF., et al. [16] \\
\hline $\begin{array}{l}\text { High Carbohydrate diet } \\
+ \text { High-fat +High-protein } \\
\text { diets }\end{array}$ & $\begin{array}{l}\text { Promote development of Bacteroide- } \\
\text { tes; Favors Prevotella genus. }\end{array}$ & $\begin{array}{l}\text { Ferment polysaccharides and indigestible } \\
\text { carbohydrates. Benefits the gut by SCFAs } \\
\text { production. }\end{array}$ & $\begin{array}{l}\text { G.D. Wu., et al. [53]; Ra- } \\
\text { joka MSR., et al. [17] }\end{array}$ \\
\hline High protein diet & $\begin{array}{c}\text { Causes riched Bacteroides associated } \\
\text { enterotype. Reduce Firmicutes. }\end{array}$ & Decrease in weight & $\begin{array}{l}\text { David La., et al. [52]; G.D. } \\
\text { Wu., et al. [53] }\end{array}$ \\
\hline $\begin{array}{l}\text { High Fat Diet and High } \\
\text { Calorie/ Western Diet }\end{array}$ & $\begin{array}{c}\text { Progressive increase in Firmicutes } \\
\text { [Mollicutes sp] and Reductions in } \\
\text { Bacteroidetes. No relation to markers } \\
\text { of energy harvest. }\end{array}$ & $\begin{array}{l}\text { Obesity leading to decrease in the gut mi- } \\
\text { crobiota diversity. Metabolic Pathways }\end{array}$ & $\begin{array}{l}\text { Murphy E F., et al. [16]; } \\
\text { Turnbaugh PJ., et al. } \\
\text { [54]; Shen W., et al. [55] }\end{array}$ \\
\hline $\begin{array}{l}\text { Less vegetable, fish and } \\
\text { fruits }\end{array}$ & Reduced microbiome & $\begin{array}{c}\text { Enhance of inflammation, triglyceride level, } \\
\text { insulin resistance and low density lipopro- } \\
\text { teins cholesterol }\end{array}$ & Matijasic BB., et al. [56] \\
\hline Gluten Free Diet & $\begin{array}{c}\text { Beneficial bacteria decreased, while } \\
\text { unhealthy bacteria increased. Reduc- } \\
\text { tions in polysaccharides intake. }\end{array}$ & $\begin{array}{l}\text { Exerted lower production of cytokines and } \\
\text { chemokines [TNF } \alpha \text {, IFN } \gamma \text { and IL-8] and } \\
\text { anti-inflammatory cytokines [IL-10] on } \\
\text { peripheral blood mononuclear cells pro- } \\
\text { inflammatory [PBMCs]. i.e. exerted lower } \\
\text { immune stimulatory effects. }\end{array}$ & Sanz, Y [58] \\
\hline $\begin{array}{l}\text { High Fiber Diet/ Plant } \\
\text { based Fibers }\end{array}$ & $\begin{array}{l}\text { Influence microbial colonization. } \\
\text { Enhance mucus and anti-microbial } \\
\text { peptide production. Major driver of } \\
\text { Prevotella-type microbiota. }\end{array}$ & $\begin{array}{c}\text { Fermentation variables results in resulted } \\
\text { in a greater short-chain fatty acid [SCFA] } \\
\text { concentration [e.g. acetic and butyric acids], } \\
\text { which help in regulating host metabolism, } \\
\text { immune system, and cell proliferation }\end{array}$ & $\begin{array}{l}\text { Makki, K., et al. [60]; } \\
\text { Nakayama J., et al. [30] }\end{array}$ \\
\hline $\begin{array}{l}\text { Calorie restricted diet } \\
\text { [CR] enriched with fibre } \\
\text { and protein }\end{array}$ & $\begin{array}{l}\text { Associated with A. muciniphila } \\
\text { abundance helped in } \\
\text { anti-inflammatory effects. }\end{array}$ & $\begin{array}{c}\text { Improvement in insulin sensitivity markers } \\
\text { and other clinical parameters in over- } \\
\text { weight/obese adults. }\end{array}$ & Dao MC., et al. [59] \\
\hline
\end{tabular}

Table 2: Studies on influence of dietary in take and its practices on gut-microbiota. 